\title{
Prevalence Of Diabetes Mellitus Among Nigerians In Port Harcourt Correlates With Socio-Economic Status
}

\author{
* NWAFOR, A ; OWHOJI, A \\ Department of Human Physiology, College of Health Sciences, University of Port Harcourt, P. M. B. 5323, Port Harcourt, Nigeria.
}

\begin{abstract}
Random blood glucose analysis by the use of the Trinder's method was carried out to determine the prevalence of diabetes mellitus among Nigerians in Port Harcourt. The study population were randomly selected and classified into two socio-economic status as high or low based on affluent diet, occupation, income and access to medical care. The mean blood glucose concentration for the high socio-economic group - staff of the oil industries was $7.42 \pm 0.25 \mathrm{mmol} / \mathrm{L}$ and significantly higher $(\mathrm{P}<0.001)$ than that for the low socio-economic class - the non- oil industrial workers, $5.33 \pm 0.45 \mathrm{mmol} / \mathrm{L}$. The prevalence of diabetes was found to be as high as $23.4 \%$ among the high socio-economic group and $16 \%$ among the low socio-economic group. Undiagonised diabetes occurred in $18.9 \%$ of the population studied and were not aware of their diabetic problem. Diabetic - awareness programmes are to be promoted with acion to identify people with diabetes early enough with the arm of providing appropriate medical treatment. @JASEM
\end{abstract}

High blood glucose, more specifically, diabetes mellitus is a major health problem (WHO, 1998). Diabetes, clinically is a non communicable disorder but diabetics as a group are at increased risk of disease states such as heart diseases, blindness, nerve disorders, kidney diseases, gangrene etc (Adetuyibi, 1976, Alberti et al 1975, Hamstem and Steiner 1994, Amos et al 1997, Edward and Raffaele 1996). The exact cause(s) of diabetic - induced complications are not fully understood, the underlying factor that appears to make those with diabetes more prone to many health problems is prolonged and frequent elevation of blood sugar. The prevalence of diabetes, in the developed countries is well established.(Alhasmi et al 1995, Rewers and Hamman, 1995, WHO 1994). The world Health Organisation stated in 1998 that a $122 \%$ rise in the number of adults with diabetes is projected by 2005, to reach 300 million adults worldwide (WHO, 1998).

The literature relating to the prevalence of diabetes in Nigeria is scarce. In so far diabetes is a well known major public health problem worldwide, there is therefore the growing tendency that every effort should be directed towards actively looking for the prevalence of diabetes in the Nigeria population. Of interest is the general impression that the prevalence of diabetes among Nigeria population in Port Harcourt is as high as and perhaps comparable with that of the Western Countries because of the urbanization and industrialization of Port Harcourt and the "Westernisation" of lifestyle of the populace. The aim and the objective of this study therefore was to investigate and compare the prevalence of diabetes among different socioeconomic groups in Port Harcourt from which the norm for Nigerians may merge and to ascertain whether or not those with high blood glucose are aware of their diabetic problem.

\section{MATERIALS AND METHODS}

Subjects for this study were randomly selected from staff of an oil company (Agip) Port Harcourt, staff and students of College of Education. Port Harcourt and the University of Port Harcourt Teaching Hospital. Respondents were ages between 17 and 60 years. The oil company workers have access to a better dietary habits, health conditions, improved education and income and were classified as high socio-economic class. The staff and students of the College of Education and University Teaching Hospitals, Port Harcourt on the other hand were classified as low socio-economic group based on the aforementioned criteria. None of the subjects were found to be hypertensive (defined as blood pressure $>$ 140/90 mmHg).

The glucose oxidase (Trinder's) method (Lett and Turner, 1975, Kannel an McGee (1979 Barham and Trinder, 1972) were employed for the study. Venous blood were obtained with a minimum of stasis into a clean disposable plastic syringe and then transferred into a universal bottle containing anticoagulant potassium fluroxide. After mixing, the blood samples were then centrifuged at $3000 \mathrm{rpm}$ for 5 minutes plasma was collected and kept at $37^{\circ} \mathrm{C}$ ready for use. Prior to use, the plasma was treated with glucose oxidase reagent and colour developed within 15 minutes. The colour that developed was measured colour metrically at $480 \mathrm{~nm}$. Statistical analysis of the data were done using comparison of proportions and paired - tests. A p-valve less than 0.05 was calculated statistically significant

\footnotetext{
* Corresponding author
} 


\section{RESULTS}

Out of 403 subjects, 141 (35\%) were staff of Agip oil company and 262 (65\%) were students and staff of the College of Education and University of Port Harcourt Teaching Hospital. The mean blood glucose concentration level of the staff of the oil company was $7.45 \pm 2.25 \mathrm{mmol} / 1$ and was significantly higher $(\mathrm{P}<0.001)$ than that for the non oil company workers $5.33 \pm 0.48 \mathrm{mmol} / 1$.This represents a difference of $68.2 \%$.

There were 64 (45.4\%) diabetics (53 or $37.6 \%$ males and 11 or $7.8 \%$ females) from a total 141 employee of the oil company studied (Table 1). Most of the employee of the oil company were males (male: female ratio 6.1:1). Thirty of the 53 (37.6\%) diabetic males were known diabetics receiving medical treatment. All the diabetic subjects have been in the employment of Agip company for more than 10 years and moreso, non presented a family history of diabetes. The duration of diabetes was less than 6 years and all the patients were non-insulin dependent diabetes (NIDDM).Forty two diabetes (20 or $7.6 \%$ males and 22 or $8.4 \%$ females) from a total of 262 non oil industrial worker were employed in the study (Table 2). The male: female ratio was $1: 1.5$.

There were 33/141 (23\%) and 42/262 (16\%) undiagnosed diabetes among the oil company staff and non oil company works respectively. The prevalence of diabetes was significantly increased $(\mathrm{P}<0.001)$ among the oil company workers than was for the non-oil company workers. The mean blood glucose concentration for the non-diabetics 77/141 (55\%) among the staff of the oil firm and for the nonoil company workers 220/262 (84\%) were similar (Tables 1 and 2). There were 76/403 (18.9\%) undiagnosed diabetes in the population and were not aware of their diabetic problem. subjects in the high socio-economic class and $5.33 \pm 0.45 \mathrm{mmol} / \mathrm{L}$ for the 262 subjects.

TABLE 1: Blood Glucose Concentration Of 141 Staff Of An Oil Company In Port Harcourt (Mean \pm Sd)

\begin{tabular}{|l|l|l|}
\hline Sex/Characteristics & Number (\%) & $\begin{array}{l}\text { Blood } \\
\text { concentration (mmol/L) }\end{array}$ \\
\hline $\begin{array}{l}\text { Male: non-diabetes } \\
\text { diabetes }\end{array}$ & $65(45 \%)$ & $5.12 \pm 0.65$ \\
\hline $\begin{array}{l}\text { Females: non-diabetes } \\
\text { diabetes }\end{array}$ & $53(37.6 \%)$ & $10.55 \pm 2.14$ \\
& $11(7.5 \%)$ & $4.85 \pm 0.86$ \\
& & $9.8 \pm 1.16$ \\
\hline
\end{tabular}

TABLE 2. Blood Glucose Concentration Of Non- Oil Company Workers

\begin{tabular}{|l|l|l|}
\multicolumn{2}{l}{ In Port Harcourt (Mean \pm Sd) } \\
\hline Sex/Characteristics & Number $(\%)$ & $\begin{array}{l}\text { Blood glucose } \\
\text { concentration } \\
(\text { mmol/L) }\end{array}$ \\
\hline Male $\quad$ :non-diabetes & $85(32.4 \%)$ & $5.19 \pm 0.38$ \\
diabetes & $20(7.63 \%)$ & $7.73 \pm 1.04$ \\
\hline Females: non-diabetes & $135(51.5 \%)$ & $4.63 \pm 0.75$ \\
diabetes & $22(8.4 \%)$ & $8.26 \pm 1.08$ \\
\hline
\end{tabular}

\section{DISCUSSION}

Diabetes mellitus is a major public health problem (who, 1998). Published information on the prevalence for Nigeria is scarce. This perhaps might be a reflection that diabetes features relatively low among the health care needs of the country. In the present study the random blood glucose concentration was found to be $7.45 \pm 0.25 \mathrm{mmol} / \mathrm{L}$ for the 141 in the low socio-economic status. The normal plasma glucose concentration varies only slightly throughout the day and the random blood glucose cut-off point for the diagnosis of diabetes range from
2.5 to $7.3 \mathrm{mmol} / \mathrm{L}$. The only rise that occurs in found after a meal but even then there is rarely a rise of more than 0.6 to $0.8 \mathrm{mmol} / \mathrm{L}$ (Superstein, 1975, WHO 1985).

The high prevalence of diabetes among the oil company workers compared to those in the non-oil industrial sectors suggests that Nigerians are prone to high rates of diabetes. Thrifty genotypes hypothesis (Lakhdar, 2000, Gill, 1996) provides attractive proposition to explain the explosive emergence of diabetes among the oil industrial workers. The hypothesis states that the population affected with high rates of diabetes 
may have genes that promoted fat deposition during periods of over - nutrition, which represented a survival advantage in times of deprivation (Lakhdar 2000). The prevalence of diabetes varies considerably around the world (Humphrey et al 1995). The high prevalence of diabetes among the oil industrial workers might be associated with affluent diet-a high fat consumption and the corresponding reduced complex carbohydrate intake and a sedentary life style (Elmugarner et al 1995).

Inspite of the small size, the present study also demonstrated that undiagonised diabetes occurred in $18.9 \%$ of the population studied and were not aware of their diabetic problem. Reports in the literature indicated that rates of undiagonised diabetes population can be high as 45 to $56 \%$ in Saudi Arabia (Al-Nuaim, 1997), 40-56\% in Egypt (Hermen et al 1995) and 30 to $40 \%$ in Bahrain (Al-Mahroos and Mekeigue 1998). Thus diabetic - awareness programmes is to be promoted with action to identify people with diabetes early enough with the arm of providing appropriate treatment regimens.

\section{REFERENCES}

Adetuyibi A 1976 Diabetes in Nigeria. African review of long term complications. Trop Geog. Med 28: 155-168.

Alberti A. K. Dornhorst A and Rowe, As 1975 Metabolic rhythms diabetes. Isr. J. Med. Sci. $11: 571$

Alhasmi MAF, Alswallem A, Wasy A. S 1995. Prevalence of Diabetes mellitus in Saudi Arabia. Saudi Med. J. 16: 294 - 299.

Al-Mahroos F, Mekeigue P. M. 1998 High prevalence of diabetes in Bahrainis. Associations with ethnicity and raised plasma cholesterol. Diabetes care 21: 936-942.

Al-Nuaim A. R. 1997 Prevalence of glucose intolerance in urban and rural communities in Saudi Arabia. Diabet Med. 14: $595 \quad-602$.

Barham D, Trinder P. 1972. An improved colour reagent for the determination of blood glucose by oxidase system. Analyst 97: 142-145

Edward SH, Raffaele N. 1996 Diabetes Mellitus. In. Zieglar E. Filler L J (eds). Present knowledge in Nutrition. ILSI Press, Washington, D. C.
Elmugarner I. T, Zayat ASA, Hossain M. M. 1995 Diabetes, obesity and hypertension in urban and rural people of Bedouin origin in the United Arab Emirates. J. Trop Med. Hyg 98: 407 - 415.

Gill G. 1996 Diabetes an increasing problem in the Middle East. International Diabetes digest 7: 1.

Humphrey ARG, Zimmet PZ, Hamman R. F. 1995 The epidomology of diabetes mellitus. In the diabetes Annual Marshall S. M., Home P. D, Rizza R. (ed). Amsterdam, Elsevier pp 131.

Hamsten A, Steiner G. 1994 Non-insulin dependant diabetes mellitus and atherosclerosis, a hypoprotein perspective. (editorial) J. intern Med. Suppl. 736: 1-3.

Herman W. H, Ali M. A. 1995 Engelhau Diabetes mellitus in Egypt, risk factors and prevalence. Diabet med 12, 1126 - 1131

Kennel W B and McGee D L 1979 Diabetes and cardiovascular disease. The Framngham study JAMA 241: 2035 - 38.

Lakhdar A. An epidemic of diabetes in the Arab world. International diabetes digest 10(3): 66, 2000.

Lett, J. A. \& Turner K 1975 Evaluation of Trinders glucose oxidase methods for measuring glucose in serum and urine. Clin. Chem 21: 1754.

Rewers M, Hamman R. F. 1995 Risk factors for noninsulin - dependent diabetes. In: Harris MI, Cowie cc, Stern MP (eds). Office, Washington De, USA.

Superstein, MD 1975 The glucose tolerance test. A pitfall in the diagnosis of diabetes

mellitus. Adv. Intern. Med. 20: 297-302.

WHO expert Committee 1985. Diabetes mellitus. WHO technical report series 727 . Geneva

World Health Organisation 1994. Prevention of diabetes mellitus. Report of WHO study group Tech. Rep. Ser. No (144) WHO Geneva.

WHO Press Release1998. WHO/63 $14^{\mathrm{TH}}$ Sept.

World Health Organisation 1985. Diabetes mellitus Report of a WHO study Group Tech. Rep. Ser. ; 727. 